Annals of Warsaw University of Life Sciences - SGGW

Land Reclamation No 38, 2007: 151-158

(Ann. Warsaw Univ. of Life Sci. - SGGW, Land Reclam. 38, 2007)

\title{
FEMWATER flow model of waste soil bank from lignite open pit mine
}

\author{
EDWARD WIENCŁAW, EUGENIUSZ KODA \\ Departament of Geotechnical Engineering, Warsaw University of Life - SGGW \\ ZBIGNIEW MAREK, TADEUSZ KACZAREWSKI \\ BOT KWB “TURÓW” S.A. Bogatynia
}

\begin{abstract}
FEMWATER flow model of waste soil bank from lignite open pit mine. The paper presents the example of numerical modelling of groundwater flow during dewatering of the TURÓW lignite open pit mine. The basis of numerical solution was the problem of groundwater flow described by Richard's equation, using 3-D finite elements method. The main purpose of the modelling carried out, taking into consideration this model, was the prediction of water logging of the waste soil bank and its surroundings. Modelling test results of the groundwater flow will be applied for extension of dewatering system and the design of monitoring system of potential threat of the waste soil bank stability, constructed in the close vicinity of lignite mine.
\end{abstract}

Key words: flow modelling, open pit mine, dewatering.

\section{INTRODUCTION}

FEMWATER model of the waste soil bank from the lignite open pit mine consists computer solution of groundwater flow for the design of this bank in TURÓW mine. The sufficient cubic capacity for waste overburden soils is necessary to continue operation of the lignite mine in TURÓW site. Since 2004 waste overburden soil is disposed on the mine open pit, where lignite resources were extracted. In 2006, shaping of subsurface of the overburden stage from the pit bottom to the level of $65 \mathrm{~m}$ a.s.1. was started. This stage is joined with the surface of tectonic fault. Next years - to 2015 , during shaping of higher stages, successive increasing of the bank crest will be to the level of 285-295 m a.s.l. The waste soil bank will be build mainly from clayey soils. The main factor, which creates geotechnical conditions of shaping and maintaining long term slope stability will be its water logging.

The basis of FEMWATER model is the solution of the problem of groundwater flow described by Richard's equation, using 3-D finite elements (Lin et al., 1997). The presented model is integrated with preprocesor/postprocessor GMS (Groundwater Modelling System) (EMRL, 2003). One of the sophisticated purposes of the analysis carried out, taking into consideration this model, was the prognosis of water logging of the overburden bank and its surroundings. The numerical analysis was carried out for the overburden bank state in 2015 .

Boundary conditions of the analysed TURÓW open pit mine and its surroundings covered by FEMWATER model are presented in Figure 1. The north-western border of the model is located 300-400 $\mathrm{m}$ to the west from Nysa Łużycka River. The north-eastern border of the model covers Miedzianka River 


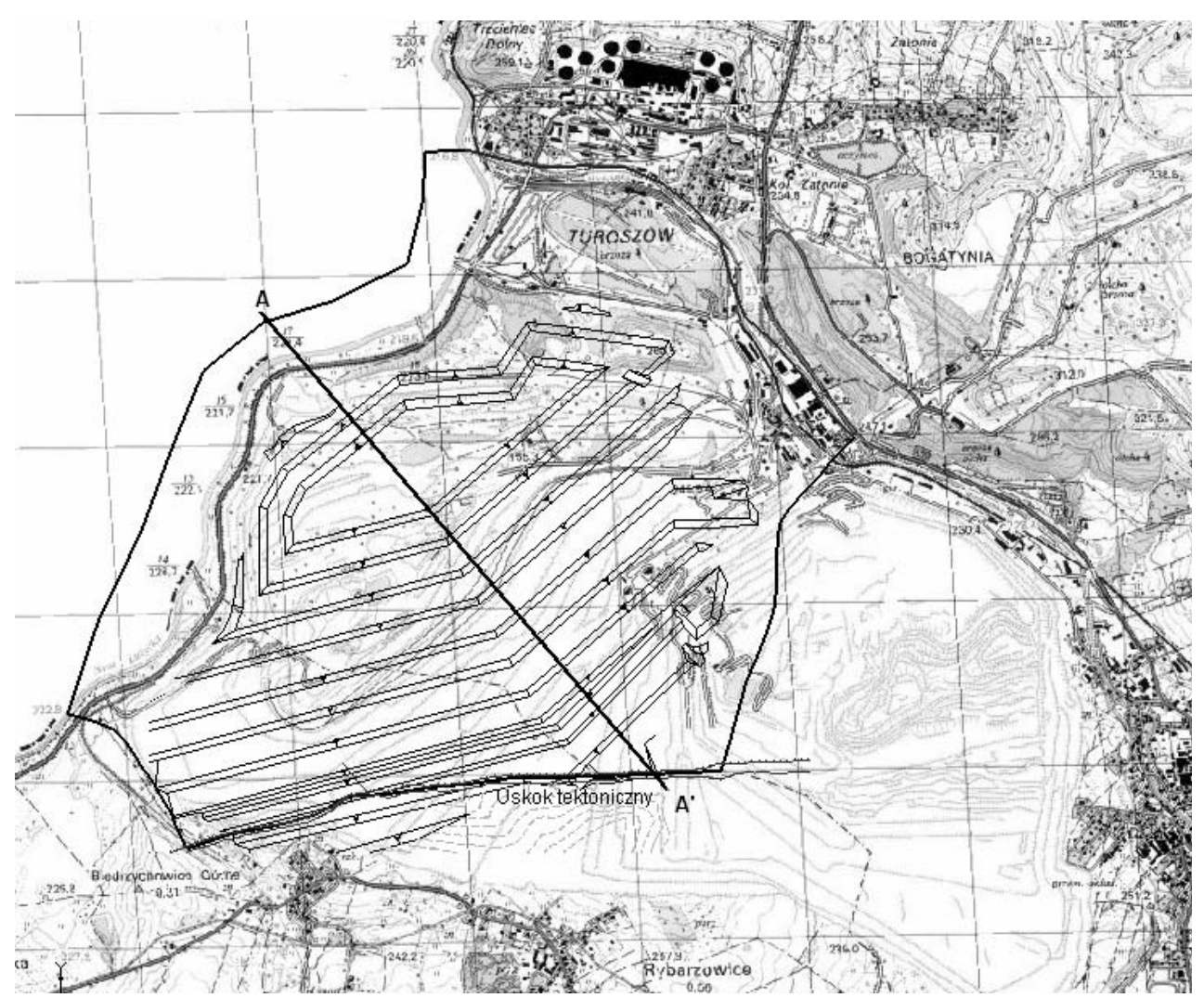

FIGURE 1. Location of the designed waste soil bank in TURÓW lignite open pit mine

bed. The southern border is agreed with direction of tectonic fault. The analysed model covered the area of approximately $13 \mathrm{~km}^{2}$.

\section{THE GOVERNING EQUATION AND ANALYSED VARIANTS}

The main equation for groundwater flow modelling is partial differential formula proposed by Richards (El-Hames and Richards, 1995):

$$
F(h) \frac{\partial h}{\partial t}=\nabla \cdot[k(h) \cdot \nabla(h+z)]+q
$$

where:

$F(h)$ - differential water capacity $(d \theta / d h)$ $\left[\mathrm{L}^{-1}\right]$,

$\theta$ - volume moisture content $\left[\mathrm{L}^{3} \mathrm{~L}^{-3}\right]$, $h$ - height of hydrostatic pressure [L], $t$ - time [T],

$k(h)=\mathrm{k}_{\mathrm{r}} \cdot k_{s}-$ hydraulic conductivity tensor $[\mathrm{L} / \mathrm{T}]$,

$k_{r}$ - relative hydraulic conductivity [-], $k_{s}-$ hydraulic conductivity tensor in saturation zone $[\mathrm{L} / \mathrm{T}]$,

$z$ - location height $[\mathrm{L}]$,

$q$ - source element $\left[\left(\mathrm{L}^{3} / \mathrm{T}\right) / \mathrm{L}^{3}\right]$.

In saturation zone; $F=0$ (search to zero in FEMWATER), $\theta$ and $k_{r}$ assumed maximum values $(\theta$ is equal to porosity, 
while $\left.k_{r}=1\right)$. In FEMWATER model, relations: $F(h), \theta(h)$ and $k_{r}(h)$ can be defined as functions described by van Genuchten (1980) or/and as linear functions.

The assumed initial conditions for flow equation:

$h=h_{i}(w, y, z)$ on $R$

where:

$R$ - dewatering mine area,

$h_{i}$ - defined initial condition, which can be received from area measuring or from solution of flow equation (2.1) for establish state.

Boundary conditions for flow equation: Dirichlet's conditions:

$h=h_{d}\left(x_{b}, y_{b}, z_{b}, t\right)$ on $B_{d}$

Neumann's conditions:

$-n \cdot k_{r} k_{s} \cdot \nabla h=q_{n}\left(x_{b}, y_{b}, z_{b}, t\right)$ on $B_{n}$

Cauchy's conditions:

$-n \cdot k_{r} k_{s} \cdot(\nabla h+\nabla \mathrm{z})=q_{c}\left(x_{b}, y_{b}, z_{b}, t\right)$ on $B_{c}$

where:

$x_{b}, y_{b}, z_{b}$ - coordinates on boundary, $\mathrm{n}-$ unit vector is normal to border, $h_{d}$ - determined value of Dirichlet's functional, $q_{n}$ - Neumann's flow, $q_{c}$ - Cauchy's flow,

$B_{d}, B_{n}$ and $B_{c}$ - borders, respectively by Dirichlet, Neumann and Cauchy.

There are possible more sophisticated "linked" conditions, which enable to consider variable conditions in precipitation period or conditions in period without rains (Kamiński et al., 1997).

The flow equation (1) subordinates both initial and boundary conditions described by equations 3,4 and 5 . This is possible to be solved by Galerkin finite elements scheme.

The model can be applied both for the fixed state of the flow and for the flow unstable with time. Presented model was calculated for state flow. The following sets of information can be calculated and printed [4]:

1. Information on the flow on the borders (changes velocity, increasing and the sum of flow through borders).

2. Hydraulic height, considered as the sum of the location level and hydraulic pressure (defined in every node).

3. The level of hydraulic pressure (defined in every node).

4. Discharge capacity (defined in every node).

5. Volume moisture content (defined in Gauss point at every element).

6. Darcy velocity (defined in every node).

\section{MODEL CONSTRUCTION \\ AND MATERIAL PARAMETERS}

The 3-D model mesh consists of 71000 elements (triangular prisms) and 38010 nodes (Fig. 2). Maximum vertical coordinate of the mesh is $295 \mathrm{~m}$ a.s.l. and corresponds with maximum coordinate of the design waste soil bank area. Minimum coordinate of the mesh is $73.5 \mathrm{~m}$ b.s.l. - adequate to the lowest point level of the bottom of the underlignite aquifer layer situated along the main tectonic fault.

On the basis of the model adequacy to recognized geological lithology and hydrogeological conditions in the vicinity of the designed waste soil bank (BOT KWB TURÓW, 2006; PROGIG, 2002; 
a

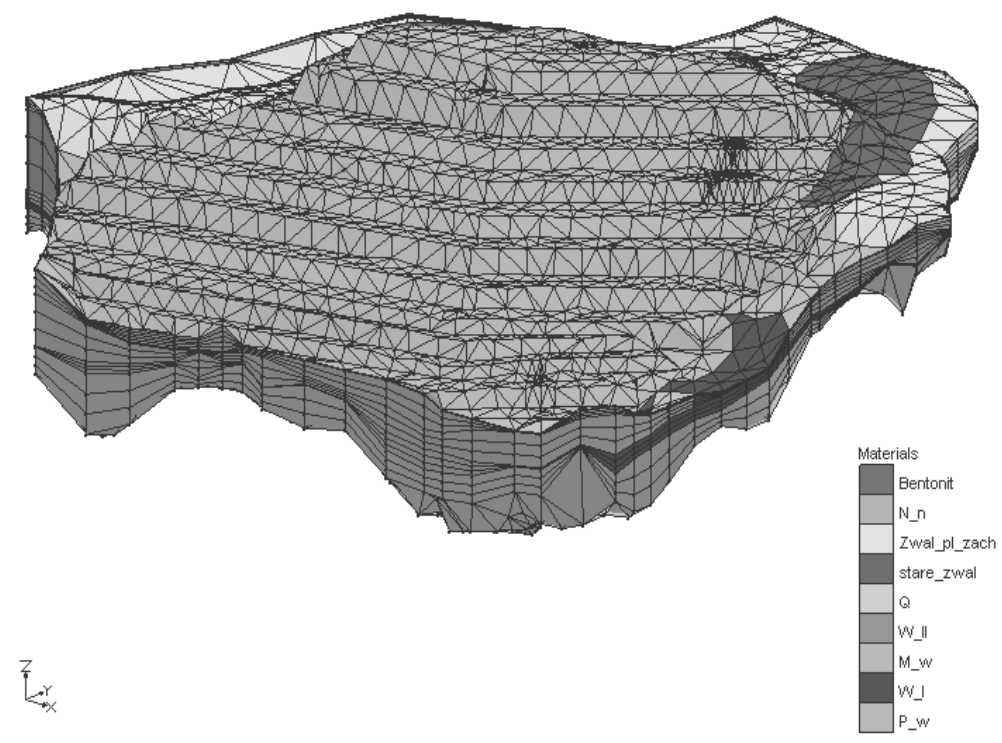

$\mathrm{b}$

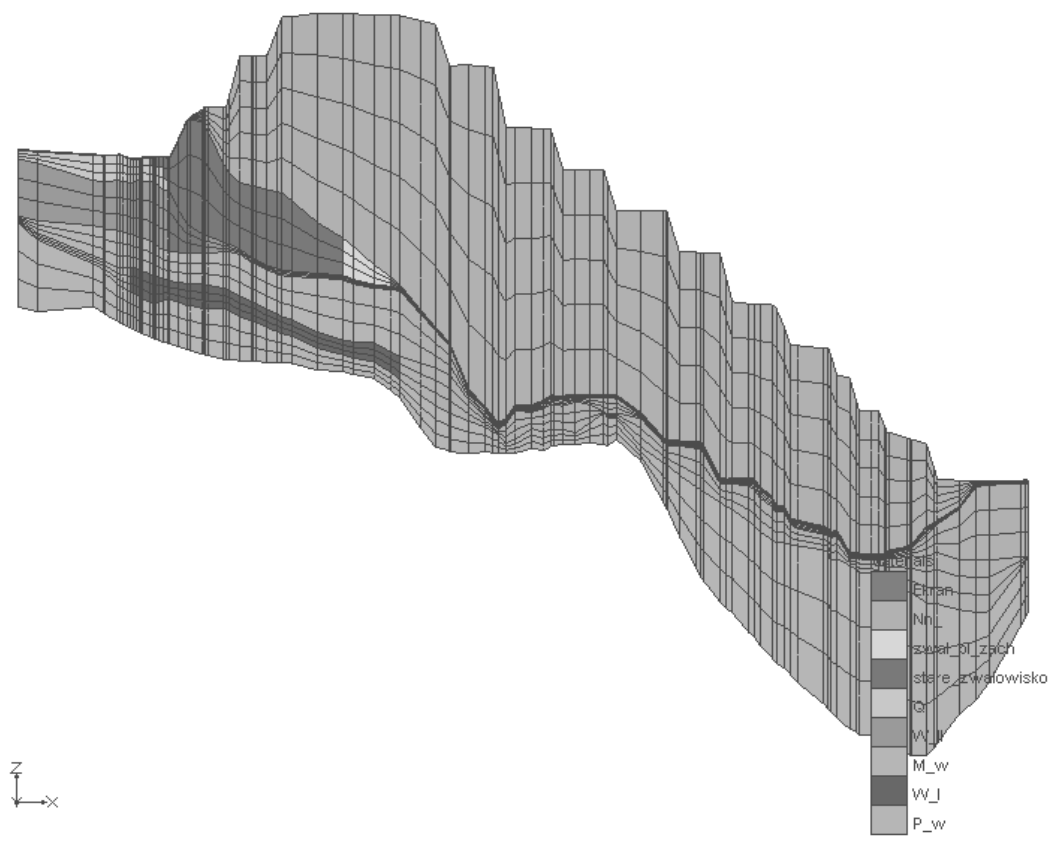

FIGURE 2. Mesh of FEMWATER model of the designed waste soil bank in TURÓW lignite open pit mine: a) 3-D view, b) A-A cross-section (higher vertical than horizontal $\times 5$ ) 
PROGIG, 2004), the space distribution of the following layers of deposit and subsoil materials were projected:

- Cut-off wall bentonite barrier, constructed along Nysa Łużycka River bed,

- Waste soils of the design waste soil bank $(\mathrm{N} n)$,

- Waste soils of the north-western waste soil bank (Zwal_pl_zach),

- Waste soils of the old overburden layers (Stary_zwał),

- Quaternary deposits (Q),

- Residual fragments of the seconds lignite seam (W_II),

- Soils of the interlignite layer (M_w),

- First lignite seam (W_I),

- Underlignite layer (P_w).

Parameter values of described deposits and subsoil layers of the model, as: hydraulic conductivity ks, differential water capacity $F(h)$, volume moisture content $\theta(h)$ and relative hydraulic conductivity $k_{r}(h)$, were presented in the Table 1.

\section{BOUNDARY CONDITIONS}

Boundary conditions of the analysed model are presented in Figure 3. The main alimentation zones of groundwater flow in the investigated part of the orogen in the open pit mine were projected on the model taking into consideration Rivers: Nysa Łużycka and Miedzianka (restrictive boundary conditions by Dirichlet).

It was assumed that the orogen would be dewatered along its southern boundary (Dirichlet's condition) and with the application of existing deep dewatering systems, i.e. well dewatering system and

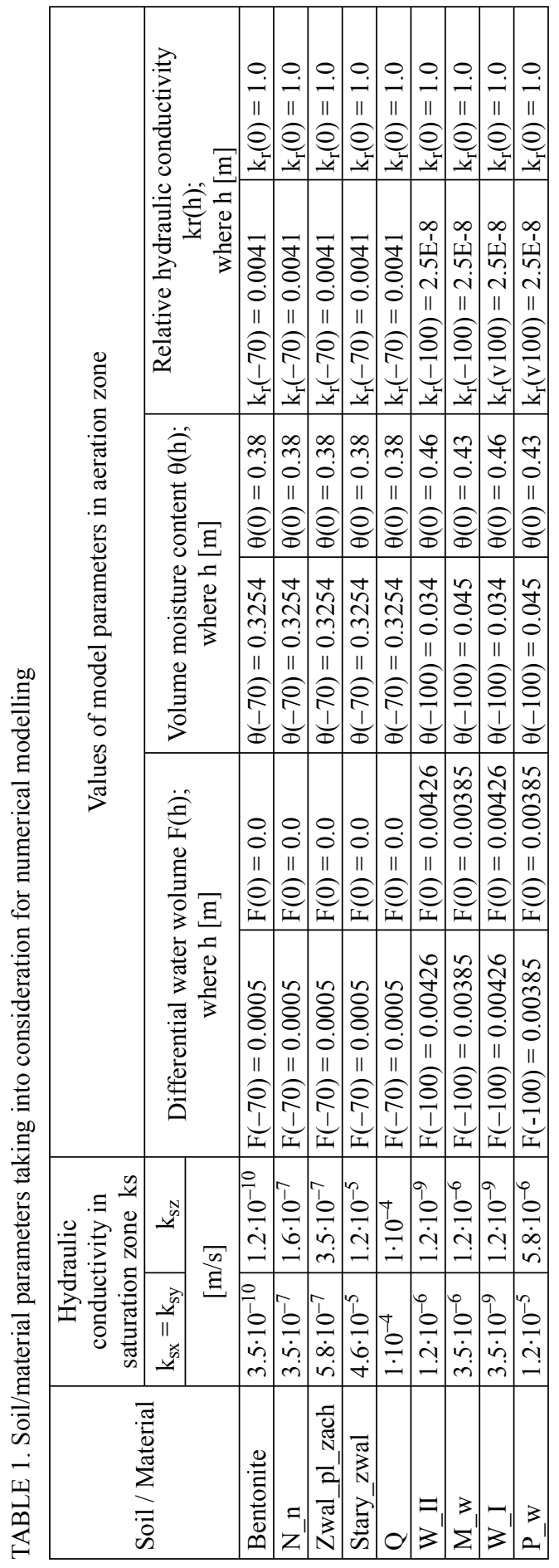


a

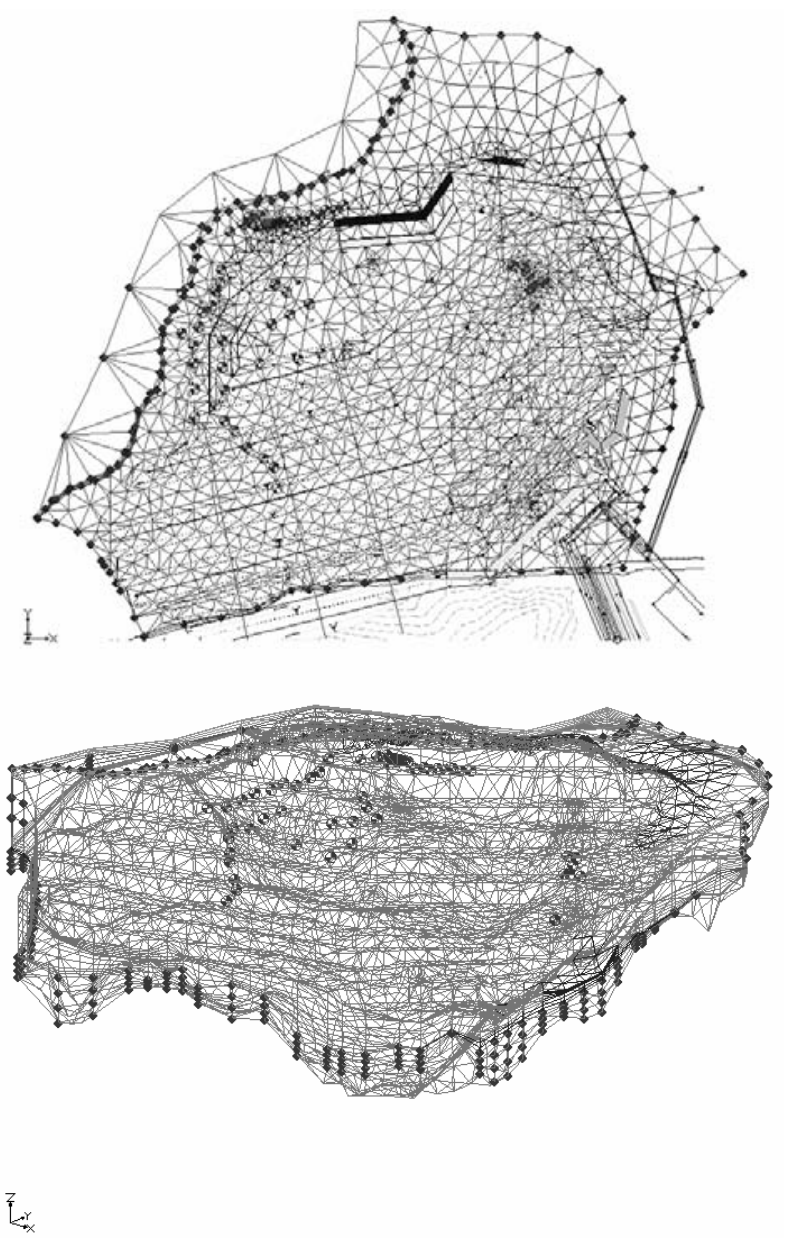

FIGURE 3. Nodes with resource function and Dirichlet boundary conditions based on FEMWATER model of the designed waste soil bank in TURÓW open pit mine: a) nodes with resource function, b) nodes with Dirichlet boundary conditions

bottom horizontal drainage system. The dewatering of the waste soil bank area, with the use of wells and horizontal drainages was constructed based on the model applying resource function $q$. The area surface was projected based on the model applying "variable" boundary conditions, i.e. Neumann's condition $q_{N}=$ $=q_{i n f}$ or Dirichlet's condition $H_{D}=H_{T}$; where: $H_{T}$ is ordinate of surface area.

\section{PREDICTION OF WASTE SOIL BANK WATER LOGGING}

The water logging means the area where subsoil is out of aeration zone. The prediction of water logging of the waste soil bank, assuming perfect protection of the waste soil bank against water infiltration from the surface, is presented in the Figure 4. The water logging zones 


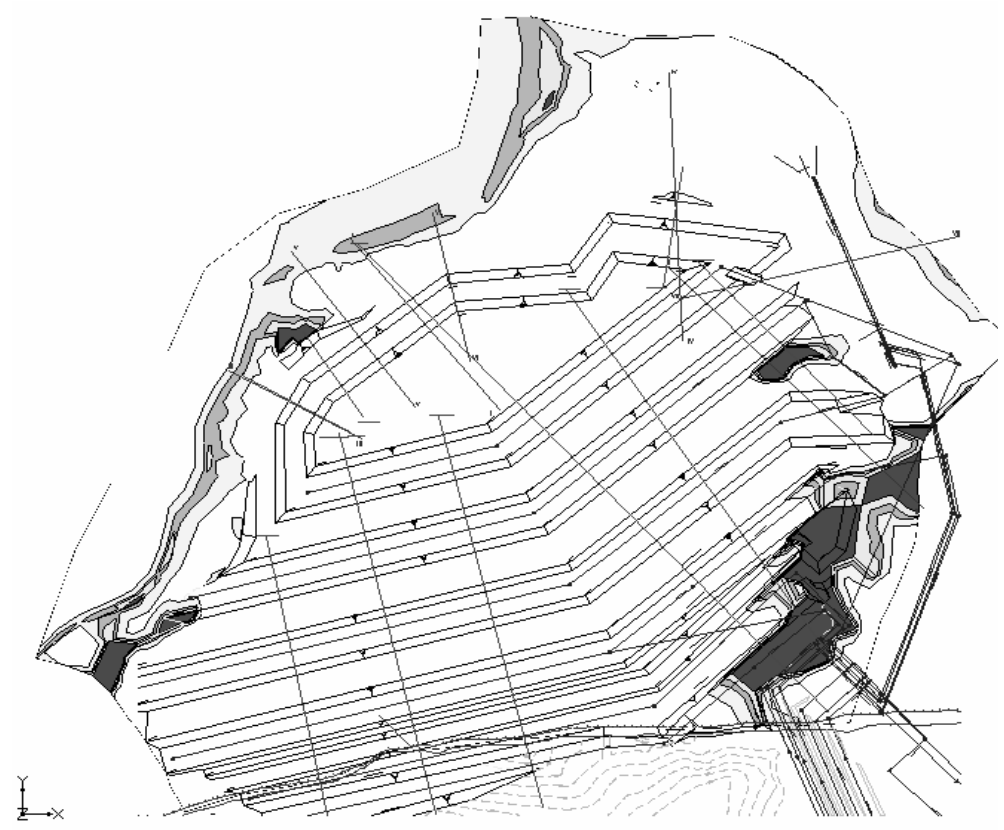

FIGURE 4. Predicted water flooding zones - modelling test results for assumed hydrogeological state without infiltration of precipitation in the body of the waste soil bank (dark colours - water logging zones, light colours - zones without water logging)

can be observed mainly in south-eastern and north-western parts of the bank.

There are following zones threatened by water logging, nearby the base of the western slope of the designed waste soil bank: area close to Nysa Łużycka River, and the north-western part of the waste soil bank and its surroundings. There are also other areas threatened by water logging: eastern part of the waste soil bank and the above slope as well as part of the south-eastern base of the waste soil bank and its surroundings.

\section{CONCLUSIONS}

Modelling test results of the groundwater flow will be applied for designing of dewatering system extending and monitoring system of potential threat of slope stability of the waste soil bank constructed in the close vicinity of objects. The mains objects which need special protection during waste soil bank construction and dewatering are: the bank of Nysa Łużycka River, international road Trzciniec-Sieniawka and industrial infrastructure around TURÓW lignite open mine.

The modelling results also will be applied in designing of adequate technical safety solutions to protect these objects.

\section{REFERENCES}

BOT KWB TURÓW 2006: Raport o stanie odwodnienia i zagrożeń wodnych za I półrocze 2006 roku. Z. Marek, A. Jakiel, J. Nowak. BOT KWB TURÓW S.A. Bogatynia, (in Polish). 
EL-HAMES A.S., RICHARDS K.S. 1995: Testing the numerical difficulty applying Richards' equation to sandy and clayey soils. Journal of Hydrology, 167, 381-391.

EMRL 2003: Groundwater modeling system tutorial. Vol. I-IV. Brigham Young University, UT.

KAMIŃSKI R., KIJKOWSKI J., WIENCŁAW E. 1997: Możliwości zastosowania programu FEMWATER w hydrotechnice. Materiały IX Konferencji Naukowej nt.; Metody Numeryczne do Projektowania i Analizy Konstrukcji Hydrotechnicznych, Kraków-Korbielów, 17-24, (in Polish).

LIN H.C., RICHARDS D.R., YEH G.T., CHENG J.R., CHENG H.P., JONEM N.L. 1997: FEMWATER: a threedimensional finite element computer model for simulating density-dependent flow and transport in variably saturated media, Technical Report CHL-97-12, U.S. Army Corps of Engineer, $151 \mathrm{pp}$.

PROGIG 2002: Dokumentacja geologicznoinżynierska i hydrogeologiczna podłoża i otoczenia północnego zwałowiska wewnętrznego w KWB TURÓW S.A. Etap II. Pacia G., Sowiński L., Tylikowski M. Biuro Projektów Górniczych i Geologicznych Sp. z o.o., Wrocław, (in Polish).

PROGIG 2004: Projekt formowania Północnego Zwałowiska Wewnętrznego i jego zboczy transportowych. Pacia G., Tomczyszyn E., Talikowski M. Biuro Projektów Górniczych i Geologicznych Sp. z o.o., Wrocław, (in Polish).
Van GENUCHTEN M.T. 1980: A closedform equation for predicting the hydraulic conductivity of unsaturated soil. Soil Science Society Journal, 44, 892-898.

Streszczenie: Model FEMWATER zwatowiska nadktadu z odkrywkowej kopalni węgla brunatnego. W artykule przedstawiono przykład modelowania numerycznego przepływu wód podziemnych podczas odwadniania odkrywki kopalni węgla brunatnego. Podstawą numerycznego rozwiązania było zagadnienie przepływu wód podziemnych opisane równaniem Richardsa $\mathrm{z}$ wykorzystaniem metody elementów skończonych dla zadania trójwymiarowego. Głównym celem podjętym podczas przeprowadzonego modelowania była prognoza możliwości wystąpienia podtopień w rejonie podstawy zwałowiska nadkładu z kopalni oraz w otoczeniu tego zwałowiska. Wyniki badań modelowych zostaną wykorzystane do projektowania rozbudowy systemu odwodnienia i systemu monitoringu potencjalnych zagrożeń stateczności zwałowiska nadkładu budowanego w sąsiedztwie kopalni.

\section{MS. received November 14, 2007}

\section{Authors' addresses:}

Edward Wiencław, Eugeniusz Koda

Katedra Geoinżynierii

Wydział Inżynierii i Kształtowania Środowiska SGGW

02-776 Warszawa, 159 Nowoursynowska St., Poland

Zbigniew Marek, Tadeusz Kaczarewski

BOT KWB "TURÓW" S.A.

59-916 Bogatynia 3, Poland 